\title{
Author Correction: Mother's Pre- pregnancy BMI and Placental Candidate miRNAs: Findings from the ENVIRONAGE Birth Cohort
}

\author{
Maria Tsamou ${ }^{1}$, Dries S. Martens $\mathbb{D}^{1}$, Ellen Winckelmans ${ }^{1}$, Narjes Madhloum ${ }^{1}$, Bianca Cox ${ }^{1}$, \\ Wilfried Gyselaers ${ }^{2}$, Tim S. Nawrot ${ }^{1,3}$ \& Karen Vrijens ${ }^{1}$
}

Correction to: Scientific Reports https://doi.org/10.1038/s41598-017-04026-8, published online 17 July 2017

This Article contains errors in Table 1.

For the miR-16, the Pre-eclampsia regulation should read '+', and the Cigarette smoke regulation should read '-' respectively.

In addition for miR-222, the row entitled 'Gestational Diabetes' should be removed respectively.

In addition, this Article contains errors in the Introduction.

"We selected a set of seven miRNAs previously shown to be expressed in human placental tissue or cell lines (Table 1), all of which are known to be related to crucial processes involved in the ontogeny or maintenance of obesity, such as inflammation, oxidative stress, apoptosis, cell cycle and angiogenesis: miR-16, miR-20a, miR-21, miR-34a, miR-146a, miR-210 and miR-222 (Table 5).”

should read:

"We selected a set of seven miRNAs previously shown to be expressed in human placental tissue or cell lines (Table 1), all of which are known to be related to crucial processes involved in the ontogeny or maintenance of obesity, such as inflammation, oxidative stress, apoptosis, cell cycle and angiogenesis: miR-16, miR-20a, miR-21, miR-34a, miR-146a, miR-210 and miR-222."

(i) Open Access This article is licensed under a Creative Commons Attribution 4.0 International (c) License, which permits use, sharing, adaptation, distribution and reproduction in any medium or format, as long as you give appropriate credit to the original author(s) and the source, provide a link to the Creative Commons license, and indicate if changes were made. The images or other third party material in this article are included in the article's Creative Commons license, unless indicated otherwise in a credit line to the material. If material is not included in the article's Creative Commons license and your intended use is not permitted by statutory regulation or exceeds the permitted use, you will need to obtain permission directly from the copyright holder. To view a copy of this license, visit http://creativecommons.org/licenses/by/4.0/.

(C) The Author(s) 2018

${ }^{1}$ Center for Environmental Sciences, Hasselt University, Diepenbeek, Belgium. ${ }^{2}$ Department of Obstetrics, East-
Limburg Hospital, Genk, Belgium. ${ }^{3}$ Department of Public Health, Environment \& Health Unit, Leuven University (KU
Leuven), Leuven, Belgium. Tim S. Nawrot and Karen Vrijens contributed equally to this work. Correspondence and requests for materials should be addressed toT.S.N. (email: tim.nawrot@uhasselt.be) 